\title{
Does computerized tomography help to shorten the immobilization period in the plaster treatment of nondisplaced scaphoid fractures?
}

\author{
(1) Hüseyin Çümen, M.D.,, ${ }^{1}$ Altuğ Duramaz, M.D., ${ }^{2}$ ๑ Cemal Kural, M.D. ${ }^{2}$ \\ ${ }^{1}$ Department of Orthopedics and Traumatology, Hakkari State Hospital, Hakkari-Turkey \\ 2Department of Orthopedics and Traumatology, Bakırköy Dr. Sadi Konuk Training and Research Hospital, İstanbul-Turkey
}

\begin{abstract}
BACKGROUND: There are conflicting results regarding the duration of the plaster treatment of nondisplaced scaphoid fractures. The aim of the present study was to evaluate the healing process and to determine the role of computed tomography (CT) on shortening the duration of plaster treatment of nondisplaced scaphoid fractures.
\end{abstract}

METHODS: A total of 42 patients diagnosed with nondisplaced scaphoid fractures between January 2012 and January 2014 were investigated. Fractures were classified according to anatomical locations and displacement degree. Fractures were short-arm plastered enclosing thumb after non-displacement was confirmed by CT. Radiological evaluation was performed using two-planned radiographs at 2-week intervals. Patients were divided into two groups as union and non-union according to their bone healing in the CT scan at week 4 of the fracture. The cast was removed in the union group.

RESULTS: Regarding anatomical location, 8 patients were classified as distal, 30 were waist region, and 4 were proximal fractures. Among 42 patients with a mean age of $31.95 \pm 13$. II years, the union was determined in $4 \mathrm{I}$ patients, and the plasters were removed at the end of 4 weeks. Patients were divided into two groups, non-union and union, in terms of fracture healing at the end of 4 weeks. There were highly statistically significant differences between the groups regarding translation degree, contact surface rates, and displacement status $(p=0.00 \mathrm{I}, \mathrm{p}=0.00 \mathrm{I}$, and $\mathrm{p}=0.00 \mathrm{I}$, respectively).

CONCLUSION: It has been shown that determination of high union rates in CT accomplishes the non-requirement of long-term plaster treatment in patients with nondisplaced scaphoid fractures after follow-up with plasters.

Keywords: Computed tomography; fracture healing; scaphoid fractures; short-term plaster treatment.

\section{INTRODUCTION}

Scaphoid fractures are the most common fractures among the carpal bone $(60 \%-70 \%)$ with a mean incidence reported as 23-43/100,000. ['] Scaphoid fractures are frequently diagnosed late or misdiagnosed since the scaphoid fracture line may not be defined clearly in standard radiographs. For that reason, early healing period problems negatively affect the prognosis. Scaphoid fractures are eligible for complications, such as non-union, malunion, humpback deformity, avascular necrosis $(\mathrm{AVN})$, or collapses in the carpal bones. The non-union rate is reported as $4 \%-10 \%$ in properly immobilized nondisplaced fractures. ${ }^{[2]}$ High healing rates are obtained with early diagnosis and appropriate treatment. The first treatment method is the conservative treatment, plaster, in nondisplaced, stable fractures with $90 \%$ to $95 \%$ healing. ${ }^{[3]}$ The duration of plaster treatment also changes according to the fracture site. Fractures of the distal pole usually heal within 6 weeks, whereas fractures involving the proximal pole may require $\geq 6$ months of plaster immobilization. ${ }^{[4]}$ There are conflicting results regarding the duration of plaster treatment in previous studies. In the literature, short-arm plasters have been suggested to

Cite this article as: Çümen H, Duramaz A, Kural C. Does computerized tomography help to shorten the immobilization period in the plaster treatment of nondisplaced scaphoid fractures? Ulus Travma Acil Cerrahi Derg 2018;24:468-473.

Address for correspondence: Altuğ Duramaz, M.D.

Bakırköy Dr. Sadi Konuk Eğitim ve Araştırma Hastanesi, Ortopedi ve Travmataloji Kliniği, İstanbul, Turkey

Tel: +90 212 - 4147 7 7 I E-mail: altug.duramaz@yahoo.com

Ulus Travma Acil Cerrahi Derg 2018;24(5):468-473 DOI: 10.5505/tjtes.2018.32069 Submitted: 14.08.2017 Accepted: 16.01.2018 Online: 10.09.2018

Copyright 2018 Turkish Association of Trauma and Emergency Surgery 
perform for 8 weeks in patients with scaphoid waist fractures. ${ }^{[5]}$ In addition, short-arm plasters have been advised to be kept for 12 weeks in the treatment of scaphoid fractures. [6] In another study, it has been shown that 6 weeks of plaster treatment in nondisplaced scaphoid fractures is enough, but treatment should be performed by long-arm plasters. ${ }^{[7]}$ Evaluation of union may not be visible in the follow-up with standard radiographs alone at 3 months, and thus computed tomography (CT) scans that contain a series performed in the longitudinal axis of the scaphoid are useful to ensure that the fracture is truly healed. ${ }^{[3]}$ Our hypothesis was that using $\mathrm{CT}$ to evaluate the bone healing in scaphoid fractures would allow in many cases to quit immobilization earlier than usually suggested by most previous studies.

The aim of this retrospective study was to evaluate the healing process and to determine the role of CT on shortening the duration of plaster treatment of nondisplaced scaphoid fractures.

\section{MATERIALS AND METHODS}

The present study was performed in accordance with the ethical standards of the 1964 Declaration of Helsinki and its later amendments or comparable ethical standards. Informed consent was obtained from all individual participants included in the study. Institutional review board approval was obtained from the local ethics committee. Patients $\geq 18$ years old, who were admitted to the orthopedics and traumatology emergency rooms between January 2012 and January 2014, and diagnosed with nondisplaced scaphoid fractures and treated with conservative short-arm plasters enclosing thumb were investigated. Patients $\leq 18$ years old, who were pregnant, with a history of previous scaphoid fractures on the same side, and who did not have CT controls on follow-up were excluded from the study. A total of 42 ( 8 female and 34 male) patients were included in the study. The mean age of the patients was $31.95 \pm 13.11$ (18-71) years. Trauma type was simple fall in 39 patients and a traffic accident in 2 patients. The cause of fracture was sports trauma in one patient who had a small cyst (2 $\mathrm{mm}$ ). In addition, the accompanying radius distal end fracture was observed in two of the patients. Fractures were localized on the distal scaphoid in 8 patients, proximal scaphoid in 4 patients, and waist of the scaphoid in 30 patients. Standard two-planned radiographs and ulnar deviated hand-wrist anteroposterior radiographs were obtained during the first admission of patient's radiographs to the emergency room (Fig. I). CT (Somatom 40 detector; Siemens, Germany) sections were obtained in the axial, sagittal, and coronal planes at I mm intervals in order to determine the fracture of the patients with suspicious physical examination results who did not have any sign of fracture in standard radiographs (Fig. 2). The radiographic evaluation also comprised an identification of fracture location (proximal, middle, or distal third), comminution, translation, displacement, and presence of a humpback deformity.

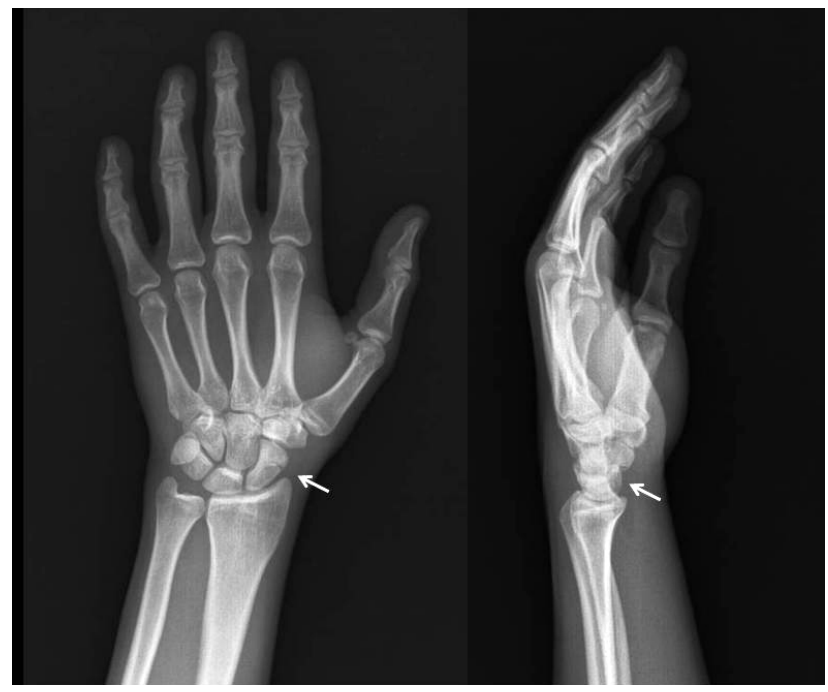

Figure 1. Anterior-posterior and lateral radiographs of the patients at first admission (white arrows show the fracture line).

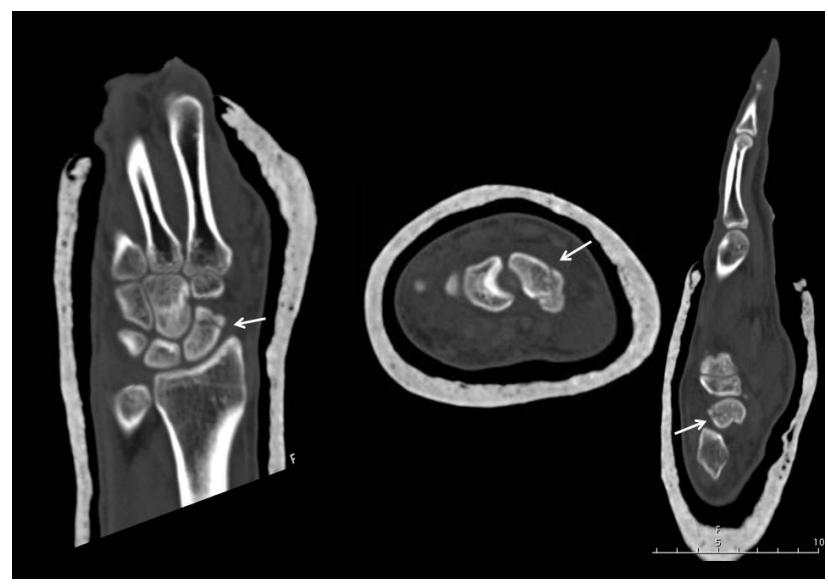

Figure 2. Axial, sagittal, and coronal CT images of the patients at first admission (white arrows show the fracture line).

Patients diagnosed with nondisplaced scaphoid fractures were treated using short-arm plasters enclosing thumb. All patients were controlled every 2 weeks clinically and radiologically. Patients were divided into two groups as union and non-union according to bone healing in the CT scan at week 4 of the fracture. Two-planned radiographs and CT evaluations were re-obtained from the patients for investigation of healing, and the plasters were removed in patients in the union group at the end of 4 weeks (Figs. 3 and 4). Patients were allowed passive exercises, but they were advised not to perform heavy exercises and contact sports. Patients without appropriate fracture healing at the end of 4 weeks were continued to be followed up with short-arm plaster, and they were informed about surgical treatment in the case of non-union. After collection of data, regarding the sagittal translation degrees observed during follow-up, fractures were classified as mildly displaced $(<1 \mathrm{~mm})$, moderately displaced $(1-1.5 \mathrm{~mm})$, and severely displaced $(>1.5 \mathrm{~mm}$ ) with the evaluation of $C T$ images at the end of 4 weeks. 


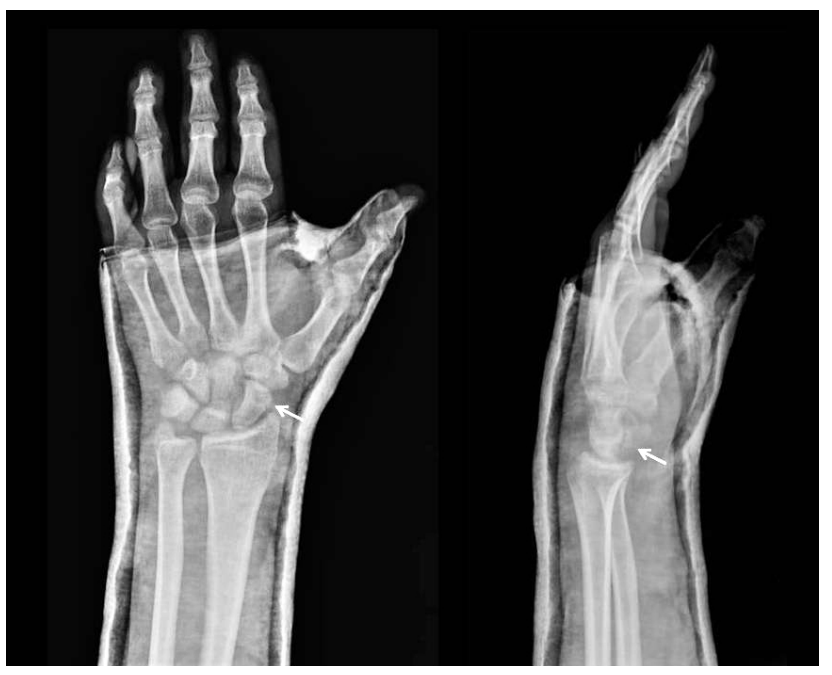

Figure 3. Anterior-posterior and lateral radiographs of the patients at the end of 4 weeks (white arrows show the healing of scaphoid fracture).

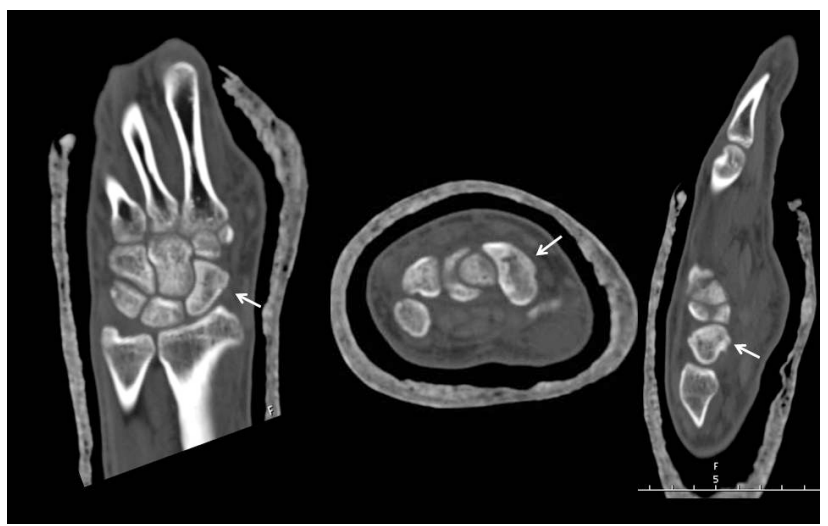

Figure 4. Axial, sagittal, and coronal CT images of the patients at the end of 4 weeks (white arrows show the healing of scaphoid fracture).

We classified the union percentage as $0 \%-24 \%, 25 \%-49 \%$, $50 \%-74 \%$, and $75 \%-100 \%$ based on the method described by Singh et al. ${ }^{[8]}$ regarding the communication between fracture fragments. Bone union was defined as the presence of at least $50 \%$ union at the fracture line with the formation of bone bridges in all CT slices. ${ }^{[9]}$ The fracture that did not accomplish at least $50 \%$ union with plaster alone was accepted as failed plaster treatment. The time to plaster removal was verified and was noticed in weeks. The patient who failed to have at least $50 \%$ union was followed up for $>3$ months with conservative treatment.

Statistical analysis was performed using the NCSS (Number Cruncher Statistical System) 2007 program (Kaysville, UT, USA). Mann-Whitney $U$ test was used for comparison of quantitative data. Fisher-Freeman-Halton test was used for comparison of qualitative data. A p value $<0.05$ was considered as statistically significant. Some parameters were statistically significant at an advanced level. A p value $<0.00$ I was used to demonstrate the advanced statistical significance.
Table I. Descriptive features of the patients

\begin{tabular}{|c|c|c|}
\hline & $\mathbf{n}$ & $\%$ \\
\hline Age (years), Mean $\pm S D$ (min-max) & \multicolumn{2}{|c|}{$\begin{array}{c}31.95 \pm 13.11 \\
(18-71)\end{array}$} \\
\hline \multicolumn{3}{|l|}{ Gender } \\
\hline Female & 8 & 19 \\
\hline Male & 34 & 81 \\
\hline \multicolumn{3}{|l|}{ Trauma type } \\
\hline Simple fall & 39 & 92.9 \\
\hline Sports trauma & I & 2.4 \\
\hline Traffic accident & 2 & 4.8 \\
\hline \multicolumn{3}{|l|}{ Accompanying fracture } \\
\hline No & 40 & 95.2 \\
\hline Distal radius & 2 & 4.8 \\
\hline \multicolumn{3}{|l|}{ Fracture location } \\
\hline Distal & 8 & 19 \\
\hline Proximal & 4 & 9.5 \\
\hline Waist & 30 & 71.5 \\
\hline \multicolumn{3}{|l|}{ Translation } \\
\hline Minimal & 37 & 88.1 \\
\hline Moderate & 4 & 9.5 \\
\hline Severe & I & 2.4 \\
\hline \multicolumn{3}{|l|}{ Union percentage at fracture line } \\
\hline $25-49 \%$ & I & 2.4 \\
\hline $50-74 \%$ & 4 & 9.5 \\
\hline $75-100 \%$ & 37 & 88.1 \\
\hline \multicolumn{3}{|c|}{ Displacement observed during follow-up } \\
\hline Mild & 37 & 88.1 \\
\hline Moderate & 4 & 9.5 \\
\hline Severe & I & 2.4 \\
\hline
\end{tabular}

SD: Standard deviation; Min: Minimum; Max: Maximum.

\section{RESULTS}

Translation was observed as minimal in 37 cases, whereas it was moderate in 4 patients and severe in I patient. Union at the fracture line was observed as between $25 \%$ and $49 \%$ in I patient, whereas it was between $50 \%$ and $74 \%$ in 4 patients and $75 \%$ and $100 \%$ in 37 patients. Displacement was moderate in 4 patients, severe in I patient, and was not observed in 37 patients (Table I). Patients were divided into two groups, non-union and union, in terms of fracture healing at the end of 4 weeks. There was no any statistically significant difference between the groups regarding the age distributions of the patients $(p=0.761 ; p<0.05)$. However, there was a highly statistically significant difference between the groups regarding translation degree $(p=0.001 ; p<0.01)$. The rate of minimal translation was significantly high among patients in the union 
Table 2. Comparison of the groups regarding bone healing with the evaluation of CT scans at the end of 4 weeks

\begin{tabular}{|c|c|c|c|}
\hline & \multicolumn{2}{|c|}{ Union situation } & \multirow[t]{2}{*}{$\mathbf{p}$} \\
\hline & Non-union & Union & \\
\hline \multicolumn{4}{|l|}{ Age (years) } \\
\hline Mean $\pm S D$ & $30.14 \pm 0.01$ & $32.31 \pm 13.74$ & ${ }^{\mathrm{a}} 0.761$ \\
\hline Min-max (median) & $30-31(30.1)$ & $|8-7|(28.0)$ & \\
\hline \multicolumn{4}{|l|}{ Translation, n (\%) } \\
\hline Minimal & $0(0)$ & $37(90.2)$ & ${ }^{\mathrm{b}} 0.00 \mathrm{I}^{* \mathrm{k}}$ \\
\hline Moderate & $0(0)$ & $4(9.8)$ & \\
\hline Severe & I (I00) & $0(0.0)$ & \\
\hline \multicolumn{4}{|c|}{ Union percentage at fracture line, $n(\%)$} \\
\hline $25 \%-49 \%$ & I (100) & $0(0.0)$ & ${ }^{\mathrm{b}} 0.00 \mathrm{I}^{* \mathrm{k}}$ \\
\hline $50 \%-74 \%$ & $0(0)$ & $4(9.8)$ & \\
\hline $75 \%-100 \%$ & $0(0)$ & $37(90.2)$ & \\
\hline \multicolumn{4}{|c|}{ Displacement observed during follow-up, n (\%) } \\
\hline Mild & $0(0)$ & $37(90.2)$ & ${ }^{\mathrm{b}} 0.00 \mathrm{I}^{* *}$ \\
\hline Moderate & $0(0)$ & $4(9.8)$ & \\
\hline Severe & I (100) & $0(0.0)$ & \\
\hline \multicolumn{4}{|l|}{ Fracture location, n (\%) } \\
\hline Distal & $0(0)$ & $8(19.5)$ & ${ }^{\mathrm{b}} 0.00 \mathrm{I}^{* *}$ \\
\hline Proximal & I (I00) & $3(7.3)$ & \\
\hline Waist & $0(0)$ & $30(73.2)$ & \\
\hline
\end{tabular}

aMann-Whitney $U$ test; ${ }^{b}$ Fisher-Freeman-Halton test; ${ }^{*} \mathrm{p}<0.01$.

group $(p=0.001 ; p<0.01)$. There was a highly statistically significant difference between the groups regarding the rate of union at fracture line and displacement $(p=0.00 \mathrm{I}$ and $p=0.00 \mathrm{I}$, respectively; $p<0.01$ ). Union at fracture line of $75 \%-100 \%$ was significantly high among patients with the union of fractures $(p=0.00 I ; p<0.01)$. The rate of mild displacement was significantly high among patients in the union group $(p=0.00 \mathrm{I}$; $\mathrm{p}<0.0 \mathrm{I}$ ) (Table 2). Fifteen patients had negative union image on radiographs but had positive union image on CT scans. All the 42 nondisplaced and 'united' fractures healed with up to 12 weeks of plaster immobilization, including $4 \mathrm{I}$ which removed the plaster at 4 weeks and mobilized.

\section{DISCUSSION}

Scaphoid fractures are the most commonly reported fractures of the carpal bones. Nowadays, treatment using plasters is selected for nondisplaced fractures, whereas surgical treatment is preferred for displaced fractures. Nondisplaced fractures define fractures without $1 \mathrm{~mm}$ displacement. In previous studies, plasters were advised to be kept for 8-12 weeks in the treatment of scaphoid fractures. According to Desai et al., ${ }^{[5]}$ short-arm plasters should be performed for 8 weeks in patients with scaphoid waist fractures. Davis et al. ${ }^{[6]}$ suggested that short-arm plasters should be kept for 12 weeks. Geoghegan et al. ${ }^{[7]}$ stated that 6 weeks of plaster treatment is enough, but treatment should be performed using long-arm plasters. Clay et al., ${ }^{[10]}$ Hambidge et al., ${ }^{[5]}$ and McQueen et al. ${ }^{\left[{ }^{I I]}\right.}$ have emphasized 8 weeks of short-arm plasters in the conservative treatment of nondisplaced scaphoid fractures.

In the literature, standard radiographs are commonly preferred for diagnosis and follow-up of scaphoid fractures. In the study performed by Low, fracture determination sensitivity with standard radiographs was defined as between II\% and $49 \% .{ }^{\left[{ }^{12]}\right.}$ Bernard et al. ${ }^{[13]}$ reported that the sensitivity of standard radiography in the determination of fracture displacement is low. Yin et al. ${ }^{[14]}$ stated that magnetic resonance imaging (MRI) is the gold standard. However, there may be some problems to differentiate edema and trabecular collapse from a fracture on the MRI sections obtained just after trauma. CT is an easily accessible and rapid imaging method. Singh reported that $C T$ is the gold standard method for the determination of scaphoid union. ${ }^{[8]}$ In evaluations performed by standard graphs, the fracture line may still be visible since the directed X-ray is parallel to the fracture line, which may cause the misdiagnosis as delayed union or non-union. ${ }^{[15]}$ Fracture healing that was not observed in standard radiographs may be defined more clearly using CT scans. In our clinic, first, standard radiographs are obtained in patients with suspicion of scaphoid fractures. CT is obtained as an additional diagnos- 
tic tool in patients without any detectable fractures in direct graphs who have positive findings on physical examination. If the fracture is defined in standard radiographs, CT is also obtained in order to determine the displacement of fracture and to define the necessity of surgical treatment. CT is re-obtained at the end of 4 weeks to evaluate the healing process in fractures conservatively treated. In the present study, we observed a union rate of $97.6 \%$ in scaphoid fractures in CT evaluations obtained at the end of 4 weeks. In addition, we determined that the rate of non-union $X$-ray images to actual union in CT imaging was $35.7 \%$. In many centers, owing to long-term plaster treatments, the joints of the patients are immobilized for a long term, causing loss of labor force. Since it is not easy to determine the union by standard radiographs, in order to eliminate the long-term plaster period, it would be more appropriate to evaluate the bone union using $\mathrm{CT}$. If union will be determined by CT evaluations at the end of 4 weeks, the plasters may be removed safely, and a gentle physical treatment may be started.

Regarding fracture locations, union periods and non-union rates are also controversial in scaphoid fractures. Especially in proximal pole fractures, non-union is more commonly reported, and the follow-up period with plaster is advised to be long. Blood supply is inadequate in proximal pole, and for that reason, $A V N$ and high non-union rates may be reported more commonly in fractures of this region. Regarding this, in clinical practice, long-term follow-up with plasters and more common surgical treatment approaches are present. Clay et al. ${ }^{[10]}$ reported a non-union rate of $31 \%$ on seven patients with proximal pole scaphoid fractures. In the study by Grewal et al. ${ }^{[16]}$ on six patients with proximal pole fractures who were followed up with $\mathrm{CT}$, the non-union rate was reported as $50 \%$. In our study, in three patients with nondisplaced proximal pole fractures who were treated with plaster, the union was determined on CT scans obtained at the end of 4 weeks. However, the union was determined on CT scans obtained at the end of 12 weeks in one patient with severe non-displacement proximal pole fractures who were treated with plaster. We believe that in those successful union results, early diagnoses and well differentiation of nondisplaced/ displaced fractures with $\mathrm{CT}$ resulting in preferring accurate treatment in relevant patients had some effects.

In our study, we also evaluated the displacement status, translation degree, and union surface rate between fracture fragments in CT evaluations obtained at the end of 4 weeks. Regarding those results, the union rates were high in patients with minimal translation. When both groups were evaluated, there was a statistically significant difference regarding union at fracture line $(p=0.001)$. Accordingly, high union rates were determined in patients with $75 \%-100 \%$ union at fracture line. In addition, there was a statistically significant difference regarding displacement $(p=0.00 \mathrm{I})$. Accordingly, the union rates were higher in patients with mild displacement on fracture line. In light of these data, we can conclude that mild dis- placement, minimal translation, and high contact surface rates between fracture fragments would be the predictors of the union in patients. When the literature was investigated, in a similar study, Low et al. reported that translation degree, bone contact surface rate, and displacement status may be the predictors of the union, but there may be some differences between observers in evaluating those markers. ${ }^{[2]}$

\section{Conclusion}

CT is a successful imaging technique in planning treatment of nondisplaced scaphoid fractures with plasters, and since it shows the union rates with high quality, we believe that it is a very effective tool in shortening plaster periods. In order to strengthen our results, randomized, controlled and larger studies are warranted.

\section{Conflict of interest: None declared.}

\section{REFERENCES}

1. Geissler WB, Adams JE, Bindra RR, Lanzinger WD, Slutsky DJ. Scaphoid fractures: what's hot, what's not. J Bone Joint Surg Am 2012;94:169-81. [CrossRef]

2. Mack GR, Bosse MJ, Gelberman RH, Yu E. The natural history of scaphoid non-union. J Bone Joint Surg Am 1984;66:504-9. [CrossRef]

3. Dias J, Kantharuban S. Treatment of Scaphoid Fractures: European Approaches. Hand Clinics 2017;33:501-9. [CrossRef]

4. Winston MJ, Weiland AJ. Scaphoid fractures in the athlete. Curr Rev Musculoskelet Med 2017;10:38-44. [CrossRef]

5. Hambidge JE, Desai VV, Schranz PJ, Compson JP, Davis TRC, Barton NJ. Acute fractures of the scaphoid. Treatment by cast immobilisation with the wrist in flexion or extension? J Bone Joint Surg Br 1999;81:91-2.

6. Davis EN, Chung KC, Kotsis SV, Lau FH, Vijan S. A cost/utility anal$y$ sis of open reduction and internal fixation versus cast immobilization for acute nondisplaced mid-waist scaphoid fractures. Plast Reconstr Surg 2006;117:1223-5. [CrossRef]

7. Geoghegan JM1, Woodruff MJ, Bhatia R, Dawson JS, Kerslake RW, Downing ND, et al. Undisplaced scaphoid waist fractures: is 4 weeks' immobilisation in a below-elbow cast sufficient if a week 4 CT scan suggests fracture union? J Hand Surg Eur Vol 2009;34:631-7. [CrossRef]

8. Singh HP, Forward D, Davis TR, Dawson JS, Oni JA, Downing ND. Partial union of acute scaphoid fractures. J Hand Surg Br 2005;30:4405. [CrossRef]

9. Hackney LA, Dodds SD. Assessment of scaphoid fracture healing. Curr Rev Musculoskelet Med 2011;4:16-22. [CrossRef]

10. Clay NR, Dias JJ, Costigan PS, Gregg PJ, Barton NJ. Need the thumb be immobilised in scaphoid fractures? A randomised prospective trial. J Bone Joint Surg Br 1991;73:828-32. [CrossRef]

11. McQueen MM, Gelbke MK, Wakefield A, Will EM, Gaebler C. Percutaneous screw fixation versus conservative treatment for fractures of the waist of the scaphoid: a prospective randomised study. J Bone Joint Surg Br 2008;90:66-71. [CrossRef]

12. Low G, Raby N. Can follow-up radiography for acute scaphoid fracture still be considered a valid investigation? Clin Radiol 2005;60:1106-10.

13. Bernard SA, Murray PM, Heckman MG. Validity of conventional radiography in determining scaphoid waist fracture displacement. J Orthop Trauma 2010;24:448-51. [CrossRef] 
14. Yin ZG, Zhang JB, Kan SL, Wang XG. Diagnostic accuracy of imaging modalities for suspected scaphoid fractures: meta-analysis combined with latent class analysis. J Bone Joint Surg Br 2012;94:1077-85. [CrossRef]

15. Dias JJ. Definition of union after acute fracture and surgery for fracture nonunion of the scaphoid. J Hand Surg Br 2001;26:321-5. [CrossRef]

16. Grewal R, Lutz K, MacDermid JC, Suh N. Proximal Pole Scaphoid Fractures: A Computed Tomographic Assessment of Outcomes.J Hand Surg Am 2016;41:54-8. [CrossRef]

\section{ORIJINAL ÇALIŞMA - ÖZET}

\section{Nondeplase skafoid kırıkların alçı tedavisinde bilgisayarlı tomografi immobilizasyon süresini kısaltmaya yardımcı olur mu? \\ Dr. Hüseyin Çümen, ${ }^{1}$ Dr. Altuğ Duramaz, ${ }^{2}$ Dr. Cemal Kural ${ }^{2}$}

${ }^{1}$ Hakkari Devlet Hastanesi, Ortopedi ve Travmataloji Kliniği, Hakkari

${ }^{2}$ Bakırköy Dr. Sadi Konuk Eğitim ve Araştırma Hastanesi, Ortopedi ve Travmataloji Kliniği, İstanbul

AMAÇ: Nondeplase skafoid kırıkların tedavisinde alçı süresi ile ilgili çelişkili sonuçlar bulunmaktadır. Bu çalışmanın amacı, nondeplase skafoid kırıkların tedavisinde iyileşme sürecini değerlendirmek ve bilgisayarlı tomografinin (BT) alçı süresinin kısaltılmasındaki rolünü belirlemekti.

GEREÇ VE YÖNTEM: Ocak 2012 ile Ocak 2014 arasında nondisplase skafoid kırığı tanısı alan 42 hasta değerlendirildi. Kırıklar anatomik yerleşim yerleri ve yer değiştirme derecelerine göre sınıflandırıldı. Kırıklar, nondeplase oldukları BT ile doğrulandıktan sonra başparmağı içeren kısa kol alçıya alındı. Radyolojik değerlendirme iki hafta aralıklar ile iki planlı grafiler kullanılarak yapıldı. Yaralanmanın dördüncü haftasında BT taramasında kemik iyileşmesine göre kaynama ve kaynamama gruplarına ayrıldılar. Kaynama grubundaki hastaların alçıları çıkarıldı.

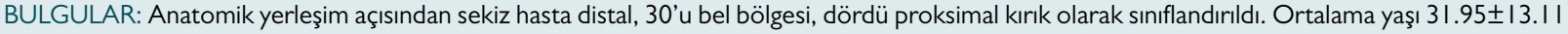
olan 42 hastanın 4 I'inde kırık iyileşmesi tespit edildi ve dördüncü hafta sonunda alçı çıkarıldı. Hastalar dördüncü haftanın sonunda kırık iyileşmesi bakımından kaynama ve kaynamama olmak üzere iki gruba ayrıldı. Translasyon derecesi, kontakt yüzey oranı ve yer değiştirme durumu açısından gruplar arasında istatistiksel olarak anlamlı farklılıklar vardı (sırasıyla, $p=0.00 \mathrm{I}, \mathrm{p}=0.00 \mathrm{I}$ ve $\mathrm{p}=0.00 \mathrm{I}$ ).

TARTIŞMA: Nondeplase skafoid kırıklarının alçıyla takibinde BT ile yüksek kaynama oranlarının saptanması uzun süreli alçı tedavisinin gerekli olmadığını göstermiştir.

Anahtar sözcükler: Bilgisayarlı tomografi; kırık iyileşmesi; kısa dönem alçı tedavisi; skafoid kırıkları.

Ulus Travma Acil Cerrahi Derg 2018;24(5):468-473 doi: 10.5505/tjtes.2018.32069 